\title{
Manuscript Collections:
}

\section{The Putnam Museum}

in Davenport

Carol Hunt

High on a bluff, amid the confluence of several of Davenport's most picturesque (and tortuously narrow) streets, the Putnam Museum overlooks the Mississippi River. It is a beautiful structure in a beautiful setting, and it is an extremely fine local and natural history museum. On the second floor, hidden from exhibits, well-organized and preserved, but out of public and, unfortunately, scholarly attention, are an amazing variety of manuscript collections. I have personally never seen a reference to any of these papers in any article or book on Iowa, much to the loss of the history of the state.

The Putnam Museum is located at 1717 W. 12th St., Davenport. The materials must be used during regular business hours, nine to five, Monday through Friday, and an appointment should be made in advance with the Director, or Mrs. Carol Hunt, Registrar, specifying the materials of interest. Mrs. Hunt offers here a glimpse into the fascinating hidden manuscript treasures of the Putnam Museum.

-David Crosson, Editor of Manuscript Collection Series

Frances Black General Store: Twelve file drawers of bound daily sales books, cash books, etc., unbound invoices, orders, shipping and receiving records, post office records. 1830-1890. 
Hampton, Illinois, is a small town located at the upper end of the Rock Island Rapids of the Mississippi River. Frances Black moved to Hampton from Vermont in 1841 and established a general store that also served steamboats taking on cargo and supplies for the trip up river. The proprietor kept records of daily sales, orders, inventory, and shipping and receiving. The collection also includes correspondence and sales literature from suppliers. The Black store served as the local post office, and the mail records are preserved. Black was active in his community, the schools, and the growth of northern Rock Island County, Illinois. These records are also a part of the collection.

Of historical interest is the kind and volume of business transacted in the early settlement period of the Quad Cities, the frequency and handling of mail to the less populated areas, and the establishment of schools and the settlement of the area. Steamboat history is here, also, in the form of servicing records and bills of lading.

James Grant Papers: Four file drawers of correspondence and records, both personal and of the law firm of Grant \& Smith. 1850-1885.

James Grant was born and educated in North Carolina and moved to Chicago in 1834 , where he read law and was admitted to the bar. In 1838 he migrated to Davenport, and from 1841-1852 he served in the territorial legislature, worked with two constitutional conventions, and spent five years as district judge. After re-entering private practice in 1853 , he never again held public office.

The firm of James Grant and S. F. Smith, in their local practice, handled the range of everyday legal business. The bulk of their work, however, was neither local nor everyday. The desire of every county for railroads in the 1850 s and 1860 s and the ensuing issuance of bonds for construction brought the inevitable defaults of payments. Many who thought they had legal claim to land discovered they did not. Indeed, the state and federal governments themselves could not agree on land titles. These were the underlying causes for the kinds of litigation that Grant \& Smith took in hand. They also worked with 
railroad company foreclosures, questions of bridge ownership, construction problems, and swamp land designations. A highly respected and well-known "country lawyer," Grant amassed a private law library that was as fine as any in the United States.

Grant's personal interests were no less demanding. He educated seventeen nieces and nephews, whom he brought to Davenport from the post-Civil War South. He was a founder and promoter of the Scott County Agricultural Association where he showed and sold pure-bred sheep and fighting cocks, raced his trotting horses. Grant was instrumental in beginning the Davenport Street Railway Company that initiated public transportation in the city, and he built and ran, through an agent, the St. James Hotel. After retiring from active law practice, he traveled in the West and later took a course in mining engineering at M.I.T. to better understand his investment in the Leadville, Colorado smelting business. He died in Oakland, California, in 1891.

Researchers will find in these papers many aspects of the early investments in railroads: the county attitudes and technicalities related to raising funds, the anxiety of eastern investors in collecting payments, the scramble for control of railroad lands, and the handling of squatters. There is correspondence concerning law suits involving land grants, the Mississippi River navigation channel, counties in Iowa, Missouri, Illinois, Nebraska, and Kansas that defaulted on their railroad bonds, and many other significant land and railroad cases. There are fleeting references to the panic of 1873 and losses from the Chicago fire. An interesting sidelight in the collection is the manner in which legal fees were charged.

Lt. George F. Hall Collections: One file drawer of records of the 2nd Division, 16th Army Corps' Quartermaster during the Civil War, plus personal correspondence. 1861-1865.

Israel Hall Collection: One file drawer of correspondence and business records of early Davenport settler, carpenter, and undertaker. Includes records of Oakdale Cemetery. 18451890.

Antoine Le Claire Papers: One file drawer of correspondence 
and business records of Davenport's founder, interpreter, businessman. 1780-1876.

A French-Indian half-breed, born and raised on the frontier, Le Claire's early years were spent traveling with his father, learning the ways of the Indian, trader, and settler. For his services as interpreter at the signing of the Black Hawk Treaty in 1832 , he was given a 640 -acre land grant that now includes LeClaire, Iowa, and another 640-acre grant now part of Davenport. He chose to settle on and develop the Davenport lands. He was the first postmaster, started the first ferry, was the first justice of the peace, and had a hand in beginning many businesses, particularly a foundry and a hotel, in partnership with Col. George Davenport. Land speculation was a major enterprise of both men, separately and together. His files have many deeds for the sale and transfer of property. He also generously provided land for city parks and land and money for both Catholic and Protestant churches.

The material in this collection can add to understanding land speculation, community growth, and the problems and progress of early settlement. The Indians trusted and respected Le Claire and freely did business with and through him. Records of these transactions remain. The early papers in the collection are in French and generally from Missouri. It is presumed that these represent the interests of his father, also Antoine Le Claire. But the son was fluent in French, as well as English and Indian dialects, so there is a sprinkling of documents in French throughout the collection.

Railroads: One half file drawer of miscellaneous and scattered papers of the Mississippi \& Missouri Railroad, Davenport \& Western Traction Co., and Des Moines \& Fort Dodge Railroad Co.

Steamboat Collection: Three file drawers plus 5,000 photographs. Business records, log books, reports, and miscellanea.

Focusing on the Upper Mississippi River, recollections and reminiscences are mixed with the more factual data of sizes and weights, disasters, and inspection reports. The donors included newspaper clippings, cruise brochures, bills of lading, tickets, and the like in the papers. The bound records of the Le Claire Marine Railway \& Lumber Co. and the Carnival 
City Packet Co., both associated with Walter Blair and Samuel Van Sant, trace the association of these two men in the steamboat business. Among the interesting documents collected by Judge W. R. Maines is the manuscript of Steven Hanks's autobiography.

One full file contains scrapbooks of newspaper clippings, many serialized, that range from the factual George Merrick record of all the boats that traveled the upper river, to the many and varied anecdotes that have grown around the business since it faded from the scene. Carefully clipped and saved are tales of navigation on tributary waterways, hoaxes, showboats, daring-do, tragedy, and even an expedition on the Nile, all of which were published in papers from St. Paul to Keokuk and Davenport to Des Moines.

Besides the Hanks autobiography, there is Walter Blair's story of his years on the river and his brief account of the Northern Packet Co. Captain Jerome Short's career fills one newspaper clipping scrapbook. Captain Merrick's Steamboats \& Steamboatmen of the Upper Mississippi River fills eight scrapbooks. Mr. Cairncross tells us stories from a deckhand's point of view, while Governor Van Sant looks upon the activities as a captain and owner.

The photograph collection includes originals and copies of steamboats on the western interior rivers in general. It also includes photographs of bridges, waterfronts, scenery, and a few of the more famous people. There are interior views, disaster pictures, locks and dams, log rafts, and other topics related to steamboating.

The research possibilities of the collection are many and varied. The story of steamboating in segmented decades or as an overall review could be researched. The separate stories of freight and passenger business or logging, rafting, and milling could be detailed. The weather conditions and ease or difficulty of navigation of the river can be found. Biographical and corporate information is available on the Davidsons, Strekfuses, Harrises, Lambs, Joe Reynolds and the Diamond Jo line, and lesser-known people and companies. Perhaps the riverfront changes that may have altered the ecological balance of the river could be investigated. There is also infor- 
mation about ferries, dredging, the navigable channels, wooding up, cargo, passengers, and schedules.

Laurell Summers Papers: One file drawer of papers of federal marshall, territorial legislator, county sheriff, and mayor of Le Claire, Iowa. Content covers mainly the taking of the federal census of 1860 and some very interesting and useful material on Democratic party politics. $1830-1890$.

Turner Society Collection: Two file drawers of records of the German Gymnastic and Social Group, mostly in German. 1871-1950s.

Isaac Wetherby Collection: One half file drawer of correspondence and business records of Iowa City photographer and artist. Collection includes $\mathbf{1 0 0 0}$ glass negatives of early Johnson County settlers. 1842-1870s.

Archives: Twelve file drawers of correspondence, financial records, reports of the Davenport Academy of Sciences, the Davenport Public Museum, and the Putman Museum. 1867 to date.

For more information on the papers outlined above, contact Carol Hunt, Registrar, Putnam Museum, 1717 W. 12th Street, Davenport 52804. 
Copyright of Annals of Iowa is the property of State of Iowa, by \& through the State Historical Society of Iowa and its content may not be copied or emailed to multiple sites or posted to a listserv without the copyright holder's express written permission. However, users may print, download, or email articles for individual use. 